\title{
Evolution of the American Zero Energy House
}

\author{
S. Russell \\ School of Architecture, Community Design, \\ University of South Florida, USA
}

\begin{abstract}
Interest in reducing energy use in buildings began in the U.S. in the 1930s with work on solar heated structures at the Massachusetts Institute of Technology. With the energy crises in the 1970s, efforts were made to reduce energy use in U.S. homes. Passive solar design involved insulated south oriented glazing systems, Trombe walls, sunspaces, flat plate collectors, thermal mass, and optimally designed overhangs. It was discovered that by reducing building cooling and heating needs through energy conservation while implementing passive solar strategies the lowest energy use at a lower incremental cost could be achieved. Super-insulated homes were successful at minimizing heat loss and gain and the subsequent load on mechanical systems, but interest subsided as energy prices dropped in the 1980s. The passive solar homes and superinsulation movements addressed passive heating and cooling, but other home energy end uses were not addressed. Throughout the late 1980s, the cost of solid state solar electricity production with photovoltaic cells declined and become affordable for individual house distributed generation. This paper is a survey of the evolution of the Zero Energy House in the U.S. and the related technologies from its experimental beginnings to its realization in several recent projects.

Keywords: energy efficiency, sustainable buildings, ZEH, solar, renewable energy.
\end{abstract}

\section{Introduction}

Today's buildings consume more energy than any other sector of the U.S. economy, including transportation and industry. Of the millions of buildings in the U.S. most were built in 1979 and prior, providing us the tremendous opportunity to reduce the nation's energy consumption by increasing the efficiency of aging buildings through retrofits or replacements as needed. 
Additionally, to address the projected increase in new construction it is essential that we improve the techniques and strategies of how we design, build, and operate our buildings for the future. In 2006, the Residential Sector consumed 37 percent of all electricity produced in the United States. The Commercial Sector consumed 36 percent and electricity expenditures made up 67 percent of total Buildings Sector energy expenditures. According to the US Department of Energy, electricity energy consumption in the sector is increasing while natural gas and petroleum energy consumption are declining and less than 2 percent of annual Buildings Sector energy consumption has been from renewable energy, each year since 1997. Space heating, lighting, and space cooling are the largest energy end-uses in the building sector with water heating and electronics in the next two spots. From this data it is clear that the design and construction of energy efficient buildings offers tangible benefits to building owners and occupants and the U.S. as a whole. Building owners can lower their energy costs by 50 percent or more while lessening maintenance and capital costs. In the process, building occupants will realize increased comfort, health and productivity and the country will conserve energy resources and enjoy cleaner air and a healthier environment [1].

\section{Energy efficient buildings in the U.S.}

Attempts at reducing energy use in buildings began in the U.S. just before World War II with work at the Massachusetts Institute of Technology on solar heated structures. The MIT Solar IV built in the late 1950s was the third test house designed by a group of engineers known as the Space Heating Committee of the Solar Energy Conversion Project, which was founded in 1938. Unlike modern photovoltaic solar cells, the cells on the MIT house were not designed to generate electricity. A 640-square foot collector tilted at a 60 degree angle provided for $57 \%$ of the building's heat during winter. Heat was stored in two basement water tanks of 1500 and 275 gallons: during the winter, the larger tank was heated by the circulation of solar heated water from the roof collectors. Water from the tank circulated through the coil of a heat exchanger to warm air blown through the house. Water from the smaller tank was heated by an oil burner and used for supplementary heat on extra cold or cloudy days. When summer came, the smaller tank was connected to the roof collectors to provide hot water for domestic use, and a low capacity refrigerator cooled the water in the larger tank to provide air conditioning. After collecting data for three heating seasons, MIT decided to sell the house to a private owner in 1962. Since no knowledgeable service organization existed to maintain the unique solar heating system, the unit was removed, and a conventional heating unit was installed. [2]

During the energy crises of the 1970s, for the first time, a concerted effort was made to reduce energy use in U.S. homes. Books like Ed Mazria's Passive Solar Energy Book were written to make the concepts of passive solar design accessible to professionals and the average person alike. Mazria writes in the acknowledgements that at the time he began writing the book in 1975 that 
"information concerning passive solar design was virtually non-existent". Passive solar design utilized insulated south oriented glazing systems, Trombe walls, flat plate collectors and sunspaces. Roof overhangs were once again thought of as a necessary feature requiring precise design. The properties of materials, their thermal mass, and reflectivity became important considerations as did the natural circumstances of the site and its micro-climate.

The 2100 sq.ft. Kelbaugh House built in Princeton, New Jersey $\left[40^{\circ} \mathrm{N}\right.$. Latitude] is representative of passive solar buildings of that era. The house features a Trombe wall solar collection system consisting of a 15" concrete wall, painted black with two sheets of double strength window glass placed in front of the wall. Heating is mainly accomplished by radiation and convection from the inside face of the Trombe wall. Vents located at the top and bottom of the wall also allow for daytime heating by convection over the warm outside facing side of the wall. According to data gathered over a one year period from 1975 -1976 the passive system reduced space heating costs by $76 \%$.[3]

At about the same time researchers at the University of Illinois were trying to reduce the heating and cooling loads in buildings by constructing a highly insulated envelope. The "Low Cal House" designed by Wayne Schick stood for "low calorie." Schick did a computational study of how much energy you could save with high levels of thermal insulation, airtight construction and heat recovery ventilation using air-to-air heat exchangers. The proposed insulation values were R-60 ceilings, R-30 walls and R-20 crawlspace floors. The Lo-Cal house was designed to illustrate how good planning and construction detailing could reduce residential energy consumption. Although never built, the Lo-Cal House attracted a great deal of national publicity and was influential in subsequent built projects like The Leger House in Pepperell, MA, one of the first double-wall super-insulated houses in the world. The 1979 heating bill for the Leger House was $\$ 38$ and remained less than $\$ 50$ per year for at least the next 10 years. [4]

The sudden influx of accessible information about passive solar design and super insulation coupled with the sudden high price of petroleum set off a temporary energy efficiency movement among architects that spread to a small counter culture but never acquired the momentum necessary to make it a popular movement. By the time the oil crisis ended and energy prices returned to an affordable level the construction of passive solar buildings all but died out. If anywhere, a lasting effect was felt in the arid western regions of the US where passive solar design is so well suited to the climate. The solar houses of the 70's had a certain functional aesthetic that was largely rejected during the historicism of the postmodern 1980's. The lack of a perceived energy crisis seemed to deal a lethal blow to the short lived energy efficiency movement in the US. While there was particular success in the reduction of heating energy [except for certain climates] cooling was not effectively dealt with nor was many other home energy end uses. Photo voltaic panels were beginning to be discussed at that time but their cost made them impractical in most applications. 


\section{The Zero Energy House}

Throughout the late $1980 \mathrm{~s}$, the cost of solid state solar electricity production with photovoltaic panels declined in price such that the possibility of using PV for individual house, distributed generation became increasingly feasible. In the state of Florida where the climate defies many passive solar design techniques the affordability of PV technology opened the door to active solar systems that would take advantage of the state's wealth of insolation that ranks second in the country only to Arizona. In 1998 the Florida Solar Energy Center began its Zero Energy Homes research program in collaboration with the City of Lakeland municipal utility and builder Rick Strawbridge.

The team constructed a 2400 sq.ft. energy efficient photovoltaic residence (PVRES) and a standard model (the Control) and tested them for more than a year. In one year, the PVRES home used $6960 \mathrm{kWh}$ of electricity and had a PV system production of $5180 \mathrm{kWh}$. For the same year, the control used 22,600 $\mathrm{kWh}$. The yearly energy savings due to differences in energy efficiency of the two homes is $70 \%$. Putting the PV system production into the numbers shows that the PVRES house's net energy use for the entire year was only $1780 \mathrm{kWh}$. When comparing the PVRES house energy, including the energy it produced, against the standard house, the PVRES house had a 92\% utility energy savings compared to the standard house. Perhaps even more important than annual energy use is the fact that during periods of peak electric demand, the PVRES home, due to the PV system, placed nearly zero net demand on the utility system. Both test homes have R-30 fiberglass insulation blown in the attic, but there are major differences in the building envelope and mechanical systems of the two buildings.

The building envelope of the PVRES house features a white mission concrete "S" tile roof. The control home's roof is conventional popular gray-brown asphalt shingles. The solar reflectance of the white S-tile tested at $77 \%$ while the reflectance of the gray-brown architectural asphalt shingle was only $7 \%$. When the outside summer air temperatures were at their peak the coincident peak attic air temperature difference was $40^{\circ} \mathrm{F}$ lower in the white tile test cell $\left(91.4^{\circ} \mathrm{F}\right)$ than the construction with black asphalt shingles $\left(131.5^{\circ} \mathrm{F}\right)$. For solar control on walls and windows, the PV home has a 3 foot overhang around the perimeter of the building while the standard home has one and a half foot overhang. At 11:10 AM on October 1st, 1997 the standard home, with a 1.5 foot overhang casts a shadow length of just 36 inches. At the same time, the shadow cast on the PV home is nearly 72 inches long. The overhang shades most of the wall and at least $75 \%$ of the south and east window area. In conventional residential construction in Florida, walls are insulated with R-3 to R-5 insulation on the interior of the masonry walls. However, the concrete block walls of the PVRES home were insulated on the exterior both in order to assist with reducing the cooling system size and to utilize the thermal mass inside the building. An exterior application of $1 \frac{1}{4}$ " Tuff- $R C$ [isocyanurate insulation] was used to encapsulate the building in R- 10 insulation so that the masonry portion of the building could be pre-cooled during the daytime hours when solar availability is high and the PV system 
output is at its maximum to utilize the thermal capacitance of the building and its masonry and help to reduce air conditioning needs during the late afternoon and early evening hours. The windows in the PVRES home are PPG Industries' Sungate 1000 solar control, low-E glass product with Argon gas fill. with a SHGC of only 0.38 , but with a daylight transmittance of $73 \%$. The center-ofglass $U$-value is 0.24 ; white thermally broken vinyl frames reduce $U$ value (overall U-value $=0.35$ ). The improved glass reduces the size for the air conditioning system. With 384 square feet of glass in the floor plan there is a $7,700 \mathrm{Btu} / \mathrm{hr}$ difference (0.64 tons) in the required size of the air conditioning system.

The mechanical systems of the two buildings also had marked differences. The HVAC systems of the two buildings were designed based on a $95^{\circ} \mathrm{F}\left[35^{\circ} \mathrm{C}\right]$ outdoor design temperature with a $75^{\circ} \mathrm{F}\left[24^{\circ} \mathrm{C}\right]$ interior temperature. The calculations indicated a 3.88 ton cooling system for the standard home (4 tons) and 1.73 ton ( 2 tons) for the PVRES house. The Trane two-ton heat pump and a variable speed indoor air handler with a combined Seasonal Energy Efficiency Ratio (SEER) of $14.4 \mathrm{Btu} / \mathrm{W}$ were selected to provide optimum efficiency, humidity removal and quiet operation. For the standard home a standard efficiency 4-ton Trane heat pump with a SEER of 10.0 Btu/W was used.

In conventional houses the ducts and often the air-handler are located in uninsulated attic space. In Florida, the attic sometimes reaches $130^{\circ} \mathrm{F}$ and studies show that heat transfer to the duct system can reduce the cooling capacity of the air conditioner by 30\%. In the PVRES house the ductwork is placed within the conditioned space of the building. Any heat gained by the duct system is removed from the conditioned space itself so there is no reduction in cooling capacity of the air conditioner. To avoid problems with leakage, the duct system was carefully sealed with mastic and tested. The duct system was oversized to provide better air flow across the evaporator, reduce air handler fan power, improve system efficiency, and reduce noise.

The PV generation system was sized to provide power that would offset most of the daytime household electrical loads. Based on the predicted loads for a peak day, it was determined that a $4 \mathrm{~kW}$ solar array should be installed. As a Utility Interactive System, the photovoltaic system is owned and maintained by the electric utility company and the power generated is supplied to the utility side of the meter. The output of the system is monitored by the utility company to evaluate the system performance and to troubleshoot problems. Systems installed such as this one increase the capacity of a service provider and can help reduce the total operating hours required for fuel-burning generators. Siemens SP75 single crystalline solar modules with a maximum power rating of $75 \mathrm{~W}$ were selected for installation on the roof of the house. The photovoltaic arrays were installed in panels, comprised of three modules each and connected in series. Thirty-six modules or 12 panels make up the south-facing sub-array and 18 modules or six panels were installed on the west face of the roof. An AC power inverter was selected to convert the array's DC power to AC for interaction with the utility grid. 
The PVRES home uses a solar water heating system with propane back up. The system consists of a forty square foot American Energy Technology AE-40 solar collector mounted on the south side of the home's roof. The collector is rated at an energy production of $45,600 \mathrm{Btu} /$ day at the low temperature $\left(95^{\circ} \mathrm{F}\right)$ rating. The Control home contains a standard electric resistance 52 gallon storage tank in the garage, rated to use $4,828 \mathrm{kWh} /$ year. The PVRES water heater has a rated energy factor of 0.65 with the measured tap hot water temperature $130^{\circ} \mathrm{F}$. Approximately $66 \%$ of the system's water heating is solar and the remainder is supplied by propane gas. Daily hot water use averaged 37.8 gallons per day against a daily propane consumption of only $3.2 \mathrm{ft} 3$ - about 0.09 gallons per day [6].

The Lakeland project was instrumental in the formation of the U.S. Department of Energy's Building America program which has led to many zero energy home and near zero energy home projects around the country. The Building America Program is responsible for reengineering new and existing American homes for energy efficiency, energy security, and affordability. Building America works with the residential building industry to develop and implement innovative building energy systems - innovations that save builders and homeowners millions of dollars in construction and energy costs. This industry-led, cost-shared partnership seeks to reduce average whole-house energy use by $30 \%-90 \%$ and reduce construction time and waste, improve indoor air quality and comfort, integrate clean onsite power systems [leading to Zero Energy Homes], and increase the energy efficiency of existing homes by $20 \%-30 \%$. The DOE has posed the "Builder's challenge" to the homebuilding industry — to build 220,000 high performance homes by 2012 [7].

\section{Zero energy communities and beyond}

With several successful examples of ZEH built across the country, the focus in recent years has become ZEH communities. In 2003 San Francisco Bay area production builder Clarum Homes partnered with Building America to build Vista Montana, the nation's largest zero-energy home community, in Watsonville, California. The development of 177 single-family homes, 80 townhouses, and 132 apartments opened in August 2003 and sold out in its first year. Clarum initially advertised prices of $\$ 379,000$ to $\$ 499,000$ but some units sold for as much as $\$ 600,000$. Every home that Clarum offered at Vista Montana features energy-efficiency measures throughout plus a package of zero energy features including a 1.2 to $2.4 \mathrm{~kW}$ photovoltaic system on the roof. Clarum partnered with ConSol and others to develop its Enviro-Home package of energy efficiency and solar power features, designed to reduce homeowner energy bills by up to $90 \%$. Each Enviro-Home has been professionally designed, certified, and inspected to reduce energy consumption and use sustainable resources while improving comfort. The program has also earned the U.S. Environmental Protection Agency's ENERGY STAR ${ }_{\circledast}$ seal, ConSol's ComfortWise designation, and the California Building Industry Institute's California Green Builder certification. In addition to a solar electric home power system, each Enviro- 
Home in the Vista Montaña community features a tankless on-demand water heater, and a high-efficiency furnace as standard features. The homes also feature a foam-wrapped building envelope, increased insulation, radiant roof barrier, advanced HVAC technology, tightly sealed ducts, and low-E energyefficient windows. Ceiling fans, fluorescent light bulbs, water conserving plumbing fixtures, and water conserving landscaping are also incorporated, providing homeowners further utility savings. The Enviro-Home incorporates sustainable building materials, such as engineered lumber, recycled decking material, and fiberglass doors, and offers recycled content carpet, bamboo flooring, cork flooring, and environmentally friendly paint as optional items. According to the developers, the Enviro-Home features that are included as standard equipment will provide more than $\$ 20,000$ of added value to homebuyers at no extra cost to them. Clarum works with Building America to use their cost and energy savings analysis to point to the most cost-effective combination of features for the climates it builds in. Once a cost-effective combination is chosen, economies of scale can be achieved through volume purchasing and training of subcontractors. Clarum is building four superefficient demonstration homes in Borrego Springs, California where temperatures routinely soar past $100^{\circ} \mathrm{F} 6$ months of the year. The homes are equipped with cutting edge wall, cooling, heating, water heating, ventilation, and PV systems.

On an even more holistic level, the NREL is assessing the feasibility of developing "renewable energy Communities" with sustainable planning, net zero-energy homes, advanced vehicles, and innovative utility interconnections that could significantly decrease energy use, as well as its associated emissions and climate change impacts, both in the U.S. and worldwide. Although there have not been any of these communities developed yet in the US, The Beddington Zero-Energy Development (BedZED) in England, is being designed to be carbon neutral, with strong emphasis on roof gardens, sunlight, solar energy, reduction of energy consumption, and waste water recycling. BedZED includes a green transport plan that promotes walking, cycling, and the use of public transport, including a car pool for residents [8].

\section{Emerging technologies}

The sustainability movement in the U.S. and world wide has stimulated research and development of many new materials and products that will be useful in building the zero energy house of the future. With the US government's pledge to invest in renewable energy and energy conservation the list of new and innovative technologies is sure to grow quickly in the near future.

In early examples of $\mathrm{ZEH}$, photovoltaic technology has been the primary source of site generated renewable energy. Hydrogen batteries and fuel cells also hold the promise of clean renewable fuel with abundant domestic sources although they are still in the development stage. Projects are currently under way at the DOE and the NREL to develop Hydrogen fuel cells for various uses from vehicles to large scale power generation to the grid and localized power 
generation for buildings. At Florida State University an Off Grid Zero Energy Building [OGZEB] demonstration utilizes Hydrogen batteries for power storage and Hydrogen production. The Hydrogen can then be used in Hydrogen burning appliances and electricity generating hydrogen fuel cells. These technologies are not yet commercially available but are nearing that stage.

To minimize the need for energy in buildings, insulation systems are critical and several promising materials are on the horizon. Aerogel, a material first discovered in the 1940s, is made by drying a gel of its liquid contents without collapsing or shrinking its matrix structure. Referred to as solid smoke, an aerogel consists of more than 96 percent air and resembles a hologram, appearing to be a projection rather than a solid object. The remaining four percent is a wispy matrix of silica (silicon dioxide), a principal raw material for glass. Aerogels, consequently, are one of the lightest weight solids ever conceived. Despite their lack of substance, these materials are the world's best solid insulator, transmitting only one hundredth the heat of normal glass. Made of inexpensive silica, aerogels can be fabricated in slabs, pellets, or most any shape desirable and have a range of potential uses. By mass or by volume, Sandwiched between two layers of glass, transparent compositions of aerogels make possible double-pane windows with high thermal resistance. Aerogels are a more efficient, lighter-weight, and less bulky form of insulation than the polyurethane foam currently used to insulate refrigerators, refrigerated vehicles, and containers. Products utilizing aerogels including roofing, glazing, insulation, and exterior wall and roof panels are currently in commercial production [9].

In terms of energy efficiency, windows are one of the biggest contributors to heat loss from buildings. A thermos insulates by separating the contents from the outside temperature with a vacuum. Heat is conducted by three modes, conduction, convection, and radiation. A vacuum prevents conduction and convection, and a reflective coating serves to reflect radiated heat back to its source. Compared to a standard double-pane window with an R-value of 3 or 4, windows with double-pane glass and a vacuum between the panes have the potential to provide insulation values comparable to a standard insulated $2 \times 4$ stud wall [R-13].

Advances in PV thin film technology have made building integrated PV systems a reality in recent years and this technology is poised to become even more pervasive in the near future. Thin film materials that replace or become a part of traditional roof or wall coverings, while maintaining and improving their insulation and protective properties are now available. While producing renewable energy from the sun, these systems go beyond photovoltaic panels by integrating design, efficiency, aesthetics and functionality. One company's product is suitable for shingle-type roofing on a wooden frame or on concrete beams with or without protective sheathing. The roof surface can be walked on with complete waterproofing for slopes up to $18^{\circ}$.

As one of the top three building end uses efficient lighting systems are critical to an energy efficient building. A Light Emitting Diode (LED) is a semiconductor device which converts electricity into light. LED lighting has been around since the 1960s, but is just now beginning to appear in the 
residential market for space lighting. LEDs are small in size, but can be grouped together for higher intensity applications. Although efficacies of up to 100 LPW have been created in laboratory settings, the efficacy of a typical residential application LED is currently approximately 20 lumens per watt compared to, Incandescent bulbs with an efficacy of about 15 LPW and ENERGY STAR $\AA$ qualified compact fluorescents at about 60 LPW. LED lights have a longer life, and are more rugged and damage-resistant than compact fluorescents and incandescent bulbs.

Hundreds of millions of dollars have been invested in OLED lighting, especially in Europe, the US and Japan. Currently, more than 130 companies and universities, and over a dozen organizations are working on OLED lighting. Compared with the other major lighting technologies in the market incandescent, fluorescent, high intensity discharge (HID) lamps, LEDs and electroluminescent (EL) - OLED lighting has several advantages. OLED lighting devices emit from the surface, can be made flexible/rollable, and even transparent like a window or reflective like a mirror. OLED lighting is thin, rugged, lightweight, and has fast switch-on times, wide operating temperatures, no noise and is environmentally friendly. The power efficiency of OLED lighting has also improved dramatically recently. The unique features of OLED lighting are inspiring the imagination of designers, who are exploring various OLED lighting applications: windows, curtains, automotive light, decorative lighting, and wallpaper. OLED lighting can have very attractive designs, can be rigid or flexible, white or color, or tunable. OLED lighting does not have ultraviolet or infrared in its spectrum, and does not generate heat during operation.

In hot humid climates air conditioning is the largest energy end use. Absorption cooling is the first and oldest form of air conditioning and refrigeration. An absorption air conditioner or refrigerator does not use an electric compressor to mechanically pressurize the refrigerant. Instead, the absorption device uses a heat source, such as natural gas or a large solar collector, to evaporate the already-pressurized refrigerant from an absorbent/refrigerant mixture. This takes place in a device called the vapor generator. Although absorption coolers require electricity for pumping the refrigerant, the amount is small compared to that consumed by a compressor in a conventional electric air conditioner or refrigerator. When used with solar thermal energy systems, absorption coolers must be adapted to operate at the normal working temperatures for solar collectors: $180^{\circ}$ to $250^{\circ} \mathrm{F}\left(82^{\circ}\right.$ to $\left.121^{\circ} \mathrm{C}\right)$. The development of micro-scale compact-type absorption chillers for residential and light commercial buildings in 2003 represents the maturation of the absorption chiller industry. The first generation of micro-scale compact-type chillers is a series of two-stage, water-LiBr based, and natural gas direct-fired systems with cooling tower. Four types of compact absorption chillers, categorized by their cooling capacity, are now on the market. Although, as of 2003 only $1 \%$ of the total installation capacity of absorption chillers was microscale compact-type systems, an increase of installations is expected in the future. 


\section{Conclusion}

With the exception of a few individuals with a broader perspective, the energy efficiency movement of the 1970's was largely a response to an economic crisis. As such, it lacked a broad backing after economic conditions improved and fuel prices returned to affordable levels. However, because it is based on a broadly acknowledged worldwide environmental crisis, the current sustainability movement is fundamentally different from its predecessor. Unlike the passive solar building movement, the sustainability movement has permeated all sectors of society and has broad acceptance and support. Even within the broad perspective of a sustainable world, buildings are being singled out along with transportation as the largest consumers of energy and contributors to $\mathrm{CO}_{2}$ emissions.

Since the proliferation of Central heating and air conditioning in the mid- $20^{\text {th }}$ century the thermal comfort range of the average American has changed several degrees making it difficult for people in extreme climate zones to live in passively heated or cooled homes. However, the principles of passive solar design can compliment highly efficient mechanical systems to greatly reduce the energy consumption of buildings. There is also evidence that comfort levels can be gradually altered when standards are placed on heating and cooling levels in buildings. In Japan, for example, the Koizumi administration fixed air conditioning in public buildings at 28 degrees Celsius and not less during the hot summer season. On a recent trip to Japan I found the warmer temperature in buildings was noticeable compared to what I have experienced there previously and what I have become accustomed to in the U.S. Although this represents a dramatic change from inside building temperatures in the 1980s [when Japan was in a bubble economy] people seem to have adjusted to the new standard with little inconvenience or discomfort. Lower building energy demand through conservation and more efficient, building envelopes, mechanical systems, appliances and passive solar strategies coupled with on-site, grid interactive, renewable energy generation through $\mathrm{PV}$, fuel cells and other emerging technologies is a proven formula for net Zero Energy Buildings that will almost certainly become the norm in the U.S. in the very near future.

\section{References}

[1] National Energy Technology Laboratory, "2008 Buildings Energy Data Book”, D\&R International, Ltd., November 2008 http://www.netl.doe.gov

[2] "Solar houses: Solar IV" MIT Libraries, Cambridge, MA http://libraries.mit.edu/guides/subjects/architecture/architects/solar/solar4.ht $\mathrm{ml}$,

[3] Edward Mazria, "The Passive Solar Energy Book”, Rodale Press, Emmaus, $\mathrm{Pa}, 1979$

[4] Joseph Lstiburek, "Westford House", Building Science Insight, Building Science.com, 5/22/09 http://www.buildingscience.com/documents/ insights/bsi-018-westford-house/, 
[5] Katrin Klingenberg, "Passive House -a Positive Net Energy Home", ISTC PDF, Illinois Sustainable Technology Center, Urbana Champaign Ill, 10/28/2008 http://www.istc.illinois.edu

[6] "ZEH: Lakeland Fl.” Florida Solar Energy Center, Orlando Fl., 2007 http://www.fsec.ucf.edu/en/research/buildings/zero_energy/lakeland/

[7] National Renewable Energy Laboratory, "Whole-House Approach Benefits Builders, Buyers, and the Environment", PDF, U.S. Department of Energy, Washington DC, 10/2004 http://www.nrel.gov

[8] Bill Dunster Architects, "BedZED - Beddington Zero Energy Development, Sutton", The Government's Energy Efficiency Best Practice programme, Crown, March 2002

[9] Jeffery Kahn, "Aerogel Research at LBL: From the Lab to the Marketplace”, Berkeley Lab science Articles Archive, Berkeley Ca., 1991 http://www.lbl.gov/Science-Articles/Archive/aerogel-insulation.html,

[10] Jennifer Colegrove, "OLED lighting set to take off in 2011," LEDS Magazine, Pennwell Corporation, Tulsa, Ok., May/June 2009 http://www.ledsmagazine.com

[11] Danny S. Parker, "Very Low Energy Homes in the United States: Perspectives on Performance from Measured Data", Florida Solar Energy Center/University of Central Florida, Cocoa Fl., August, 2008 http://www.fsec.ucf.edu

[12] Benjamin Stein, John S. Reynolds, "Mechanical and Electrical Equipment for Buildings", John Wiley and Sons, New York, NY, 2000

[13] Fred Mitlitsky (Primary Contact), Jim McElroy, Karla Conmy, "Low-Cost Co-Production of Hydrogen and Electricity", 2008 Annual Progress Report, DOE Hydrogen Program, Washington DC, 2009 http://www.energy.gov

[14] Danny Parker, David Hoak, Alan Meier, Richard Brown, "How Much Energy Are We Using? Potential of Residential Energy Demand Feedback Devices", Florida Solar Energy Center/ University of Central Florida, Cocoa fl., August 2006 http://www.fsec.ucf.edu 